\title{
Photolysis of ortho-nitrobenzylic derivatives: the importance of the leaving group
}

\author{
Tomáš Šolomek,ł Sébastien Mercier,§ Thomas Bally* and Christian G. Bochet*
}

\begin{abstract}
Quantum yields for the photoinduced release of seven different commonly used leaving groups (LGs) from the $o$-nitroveratryl protecting group were measured. It was found that these quantum yields depend strongly on the nature of the LGs. We show that the quantum efficiency with which the LGs are released correlates with the stabilization that these LGs provide to $o$-nitrobenzyl-type radicals because radical stabilizing groups weaken the $\mathrm{C}-\mathrm{H}$ bond that is cleaved in the photoinduced hydrogen atom transfer step, and hence lower the barrier for this process. At the same time these substituents lower the endothermicity of the thermal hydrogen atom transfer and thus increase the barrier for the reverse process, thereby enhancing the part of the initially formed aci-nitro intermediates which undergo cyclization (which ultimately leads to LG release). Radical stabilization energies computed by DFT methods are thus a useful predictor of the relative efficiency with which LGs are photoreleased from $o$-nitrobenzyl protecting groups.
\end{abstract}

\section{Introduction}

Since their introduction in the mid $1960 \mathrm{~s},{ }^{1-4}$ photolabile protecting groups (PPGs) have taken an increasing importance in organic synthesis, ${ }^{5-7}$ surface science ${ }^{8-10}$ and biology, ${ }^{11,12}$ where they are also called caging compounds. ${ }^{13}$ The possibility of releasing a reactive species at a given time and in specific space by a non-chemical stimulus - a light beam - is an attractive tool for many applications, ranging from total synthesis of natural products, ${ }^{14}$ DNA-chip manufacturing ${ }^{15,16}$ or neurophysiological studies. ${ }^{17}$ ln the growing family of PPGs, the $o$-nitrobenzyl group is one of the oldest, but still widely used groups, mainly due to its robustness and relative photophysical insensitivity to interfering influences. There have been many studies, both experimental and computational, on the mechanism of the photoinduced decomposition of this kind of PPGs ${ }^{18-26}$ but many unanswered questions remain, such as the impact of substituents in various positions, and the origin of an intriguing kinetic isotope effect. ${ }^{27,28}$

For example, it has been shown that the quantum yields $\phi$ for the disappearance of nitrobenzyl PPGs, or those for the release of the leaving groups, depend strongly on the chemical character of the leaving group (LG). However, it is unclear which feature of a LG determines its influence on these quantum yields. Apparently it is not the nucleofugacity, since quantum yields for

Department of Chemistry, University of Fribourg, Chemin du Musée 9, 11700 Fribourg, Switzerland. E-mail: Thomas.Bally@unifr.ch, Christian.Bochet@unifr.ch

† On leave from Masaryk University, Brno, Czech Republic.

$\S$ Current address: Syngenta Crop Protection AG, Monthey, Switzerland. the decay of the 4-acetyl-2-nitrobenzyl protected benzylalcohol in methanol was found to be 0.88 while it was only 0.051 for the corresponding phenylacetic acid. ${ }^{29}$

In this paper we propose a simple predictive model to explain a series of quantum yields for the release of seven different commonly used leaving groups from $o$-nitroveratryl PPGs. Based on a minimal mechanistic scheme, these values are correlated with a measure that can be evaluated easily using standard quantum chemical calculations.

\section{Results}

\subsection{Preparation of the substrates}

We have investigated seven compounds (1a-g) with different types of leaving groups at the benzylic position (Fig. 1); they are all derived from the widely used nitroveratryl core.

Their preparation was achieved using established procedures (Scheme 1). Ether 1a was prepared by a silver oxide-mediated etherification of nitroveratrol, whereas amine $\mathbf{1 b}$ was prepared by reductive amination of nitroveratraldehyde with dodecylamine. Carbamate 1c and amide 1d were both prepared by acylation of amine 4, which itself was prepared by reduction of the nitroveratraldehyde oxime acetate $\mathbf{3}$ resulting from acylation of $\mathbf{2}$, with the corresponding carbonic acid chloride or acid chloride. Carbamate 1e and carbonate $1 \mathrm{~g}$ were prepared by reaction of commercially available nitroveratryl chloroformate with dodecylamine and decanol, respectively. Finally, the ester 1 f was prepared by a DCC-mediated esterification of tridecanoic acid with nitroveratrol. All products were pure, and fully characterized. Details of the syntheses are given in the Methods section. 


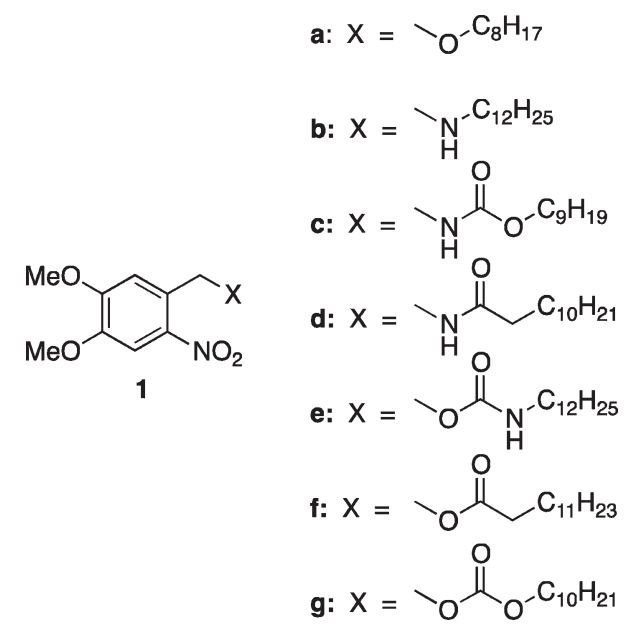

Fig. 1 Substrates investigated in the present study.

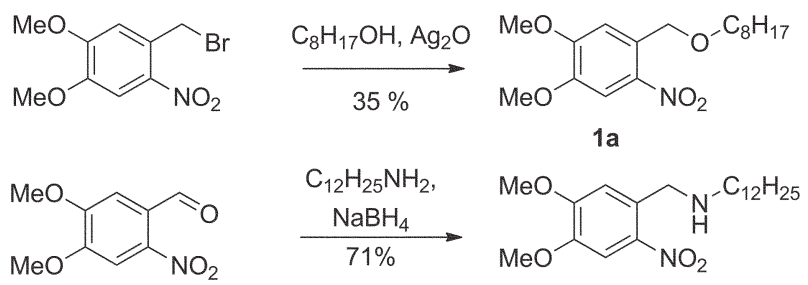

$1 \mathrm{~b}$<smiles>COc1cc(C=O)c([N+](=O)[O-])cc1OC</smiles>

$\mathrm{H}_{2} \mathrm{NOH} \cdot \mathrm{HCl}$ pyridine

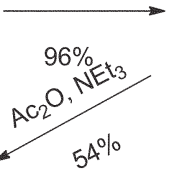<smiles>CN=Cc1cc(OC)c(OC)cc1[N+](=O)[O-]</smiles>
$\mathrm{BH}_{3}$, THF

$12 \%$

$\mathrm{RCOCl}$, base<smiles>COc1cc(CN)c([N+](=O)[O-])cc1OC</smiles>
$65-99 \%$ 4<smiles>[R]O[Na]</smiles>

$$
\begin{aligned}
& \text { 1c: } R=O_{9} H_{19} \\
& \text { 1d: } R=C_{11} H_{23}
\end{aligned}
$$<smiles>[R]C(=O)OCc1cc(OC)c(OC)cc1[N+](=O)[O-]</smiles>

1e: $X=\mathrm{NH}, \mathrm{R}=\mathrm{C}_{12} \mathrm{H}_{25}$ 1g: $X=O, R=C_{10} \mathrm{H}_{21}$<smiles>COc1cc(CO)c([N+](=O)[O-])cc1OC</smiles>

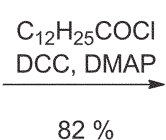<smiles>CCCCCCCC(=O)OCc1cc(OC)c(OC)cc1[N+](=O)[O-]</smiles>

Scheme 1 Preparation of compounds 1a-g.

\subsection{Quantum yield measurements}

The derivatives $\mathbf{1 a}-\mathbf{g}$ were photolysed in acetonitrile $(c \sim 1 \times$ $\left.10^{-3} \mathrm{M}\right)$ in a LED-based reactor at $360 \mathrm{~nm}$ for a given time enduring a small conversion $(<10 \%)$, which was then determined

Table 1 Quantum yields for the disappearance of compounds 1a-g on photolysis at $360 \mathrm{~nm}$

\begin{tabular}{lll}
\hline Substrate & Leaving group (LG) & $\Phi_{360}{ }^{a}$ \\
\hline $\mathbf{1 a}$ & $\mathrm{O}-\mathrm{C}_{8} \mathrm{H}_{17}$ & $0.22 \pm 0.04$ \\
$\mathbf{1 b}$ & $\mathrm{NH}-\mathrm{C}_{12} \mathrm{H}_{25}$ & $0.14 \pm 0.01$ \\
$\mathbf{1 c}$ & $\mathrm{NHC}(\mathrm{O}) \mathrm{O}-\mathrm{C}_{9} \mathrm{H}_{19}$ & $0.080 \pm 0.003$ \\
$\mathbf{1 d}$ & $\mathrm{NHC}(\mathrm{O}) \mathrm{CH}_{2}-\mathrm{C}_{10} \mathrm{H}_{21}$ & $0.072 \pm 0.013$ \\
$\mathbf{1 e}$ & $\mathrm{OC}(\mathrm{O}) \mathrm{NH}_{2}-\mathrm{C}_{12} \mathrm{H}_{25}$ & $0.019 \pm 0.005$ \\
$\mathbf{1 f}$ & $\mathrm{OC}(\mathrm{O}) \mathrm{CH}_{2}-\mathrm{C}_{11} \mathrm{H}_{23}$ & $0.0081 \pm 0.0005$ \\
$\mathbf{1 g}$ & $\mathrm{OC}(\mathrm{O}) \mathrm{O}-\mathrm{C}_{10} \mathrm{H}_{21}$ & $0.0091 \pm 0.0013$ \\
${ }^{2}$ Acetonitrile solutions $\left(\sim 1 \times 10^{-3} \mathrm{M}\right)$ were irradiated at $\lambda=360 \pm 5 \mathrm{~nm}$ \\
(LED-based reactor). $\Phi$ was determined by actinometry using \\
phenylglyoxylic acid. Standard deviations from two independent \\
measurements are shown.
\end{tabular}

by HPLC (see section on Methods). Quantum yields were obtained from these conversions, against phenylglyoxylic acid actinometry, and are summarized in Table 1.

It is immediately apparent that ethers and amines have a strong beneficial effect on the quantum yields for photodecomposition, whereas electron-withdrawing substituents on the oxygen and nitrogen significantly reduce the efficiency of the reaction.

\section{Discussion}

In general terms, there are three critical steps in the release mechanism of $o$-nitrobenzyl derived PPGs (5, Scheme 2): (i) the photoinduced $\mathrm{H}$-atom transfer (HAT*) leading to the primary aci-nitro intemediates 6, (ii) ground state cyclization of $\mathbf{6}$ to benzo $[c]$ isoxazol-1 $(3 H)$-ols 7 , which competes with (iii) reverse HAT to re-form 5. In basic media, 7 is deprotonated and cleaves irreversibly, by concomitant release of $\mathrm{X}^{-}$, to $o$-nitrosobenzaldehydes 8.

Regarding the competition between the ground state reactions (ii) and (iii), Il'ichev has previously shown that their branching ratio does not change enough for different leaving groups of the type considered in our study to explain the observed variations in quantum yields (it invariably favors the cyclization to 7). ${ }^{30}$ Thus we will disregard these reactions as determinants for the<smiles>[R]c1ccc([N+](=O)[O-])c(C([Y])([2H])[2H])c1</smiles>

5<smiles>[X]C=C1C=CC(=[N+]([O-])O)C([R])C=C1</smiles>

6<smiles>[3H][B-]</smiles>

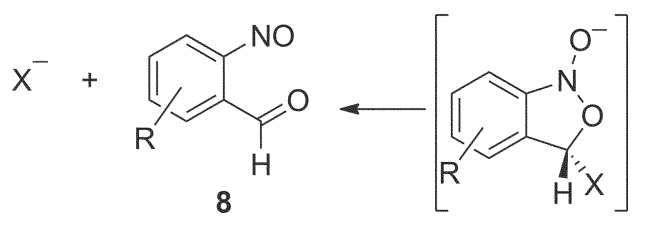

Scheme 2 Simplified mechanism of the photofragmentation of $o$-nitrobenzyl compounds. 
<smiles>Cc1cc2c(cc1[N+](=O)[O-])OCO2</smiles>

a: $X=\mathrm{OMe}$

b: $X=N H M e$

c: $X=\mathrm{NHCOOMe}$<smiles>[X]C([CH])c1cc2c(cc1[N+](=O)[O-])OCO2</smiles><smiles>CCc1cc2c(cc1[N+](=O)[O-])OCO2</smiles><smiles></smiles>

quantum yield of product formation in our set of molecules and focus on the step (i).

According to recent experimental and computational evidence this HAT* step occurs from a (singlet and triplet) excited state, and it involves a barrier. ${ }^{24,31,32}$ It would therefore appear reasonable to assume that the height of this barrier scales with the strength of the critical $\mathrm{C}-\mathrm{H}$ bond (marked red in Scheme 2). We based our computational exploration on the premise that this bond strength, although it is certainly much smaller in the (singlet or triplet) excited state, is affected similarly by the presence of different LGs $\mathrm{X}$ as it is in the ground state. LGs which lower the barrier for photoinduced 1,5-hydrogen atom transfer, HAT*$^{*}$, should allow this process to compete more efficiently with other deactivation processes and thus increase the quantum yield of LG release. A similar approach has been recently employed by Yamaji et al. ${ }^{33,34}$

Instead of calculating $\mathrm{C}-\mathrm{H}$ bond dissociation energies, which are potentially subject to large errors due to the unavoidable neglect of a part of the correlation energy, we calculated radical stabilization energies (RSEs), i.e. differences in $\mathrm{C}-\mathrm{H}$ bond dissociation energies for $\mathrm{X}=\mathrm{H}$ and $\mathrm{X}=\mathrm{LG}$ in a series of model compounds, according to the isodesmic reaction depicted in Scheme 3. The enthalpy change in the course of this reaction corresponds to the stabilization of the radical $9^{\circ}$ offered by $\mathrm{X}$ (relative to $\mathrm{H}$ ).

To avoid having to deal with a multitude of conformers we modified the structures of the nitroveratryl derivatives $\mathbf{1 a - g}$ by "tying up" the two methoxy groups in an acetal moiety, and by replacing the long alkyl chains in the LGs by methyl groups. The electronic structure of the compounds $\mathbf{9 a}-\mathbf{g}$ in Scheme 3 should very closely resemble that of compounds $1 \mathbf{1 a}-\mathbf{g}$ with different LGs as X.

Note that the radical stabilization energies to be used in this study cannot be replaced by values from tables ${ }^{35}$ which usually refer to the methyl radical as a standard, because pairs of substituents can interact, often to different extents in the closed-shell precursors and in the radicals, and thus make that RSEs are not additive. ${ }^{36}$ Here, one of the radical substituents is the nitrophenyl moiety, and it is necessary to account for the presence of this substituent in the evaluation of the relative stabilization that additional substituents $\mathrm{X}$ provide to radicals $\mathbf{9}^{\circ}$.

First we performed the calculations in the gas phase, searching for the lowest energy conformers of $\mathbf{9 a - g}$ and their corresponding radicals. It turned out that a low energy conformer with an
Table 2 Radical Stabilization Energies (RSEs)

\begin{tabular}{lll}
\hline Structure & $\mathrm{RSE}^{a}$ & $\Phi_{360}{ }^{b}$ \\
\hline 9a & 11.5 & 0.22 \\
9b & 20.2 & 0.14 \\
9c & 9.7 & 0.08 \\
9d & 10.4 & 0.072 \\
9e & 9.1 & 0.019 \\
9f & 10.0 & 0.0081 \\
9g & 6.6 & 0.0091
\end{tabular}

${ }^{a}$ Radical stabilization energy in $\mathrm{kcal} \mathrm{mol}^{-1}$ calculated with the PCM method (acetonitrile) by UB2PLYP/6-311+G(3df,2p)//UB3LYP/6-31G (d) according to Scheme 4 including ZPVE corrections scaled by 0.9806 (i.e. $\Delta H$ at $0 \mathrm{~K}) ;{ }^{b}$ Experimental quantum yield for the decomposition of the corresponding derivative of $\mathbf{1}$ measured in this work; taken from Table 1.

intramolecular $\mathrm{N}-\mathrm{H}$...ONO hydrogen bond exists in 9c and 9d which is probably no longer present when the photolysis is done in a polar solvent, especially if residual moisture is present, as is the case in acetonitrile. Therefore we reoptimized all the structures in polarizable continuum to simulate the collective effects of the solvent environment. Now the energy difference between the conformers of $9 \mathbf{c}$ and $9 \mathbf{d}$ with and without the intramolecular H-bond dropped to $<1.0 \mathrm{kcal} \mathrm{mol}^{-1}$.

Thus we decided to present the results calculated for structures without any internal $\mathrm{H}$-bonding interaction in order to create a consistent picture based only on the electronic properties of LGs. The B2PLYP PCM results together with those from quantum yield measurements are summarized in Table 2 (for details of all calculations see ESI $\dagger$ ).

If our hypothesis is correct, and if the quantum yields of LG release depend on the barrier of reaction (i), then that barrier should decrease and the corresponding quantum yield should increase with increasing RSE. A plot relating the disappearance quantum yields of 1 on irradiation at $360 \mathrm{~nm}$ with calculated radical stabilization energies is shown in Fig. 2.

Indeed our results suggest that leaving groups in the benzylic position of the nitroveratryl group which better stabilize the corresponding radical are released more efficiently. The correlation is not (and cannot be) linear, because the maximum value of $\Phi$ must be 1 unless a chain process is present, and the $\Phi$ vs. RSE plot should show a sigmoidal shape as expected for a reaction with one or more competing processes. 


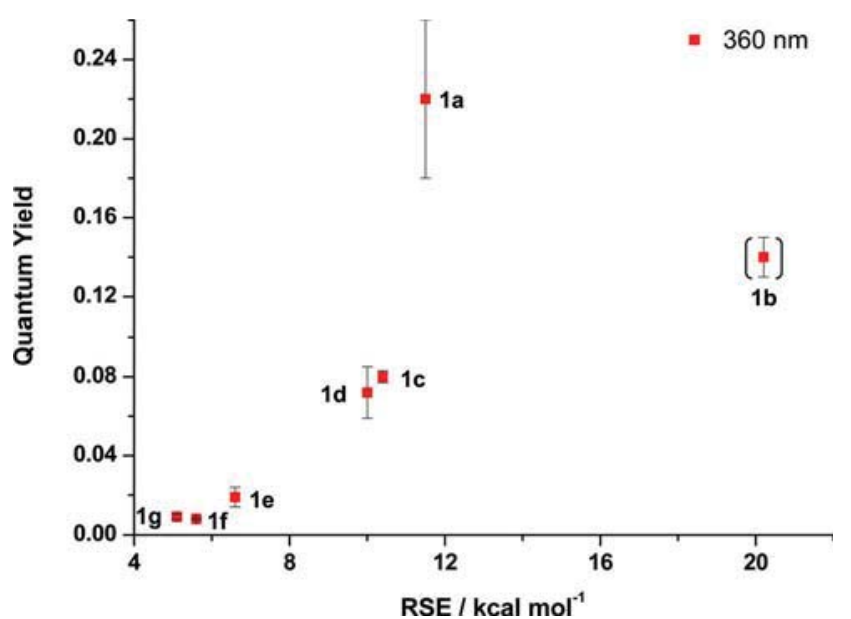

Fig. 2 Quantum yields for the disappearance of $o$-nitroveratryl-PPGs 1a-g on irradiation at $360 \mathrm{~nm} v s$. radical stabilization energy (RSE) for different leaving groups in compounds $\mathbf{9 a}-\mathbf{g}$. The outlier is shown in parentheses (see text for discussion); standard deviation for each point is included.

However, the $\Phi$ of $\mathbf{1 b}$ is smaller than that measured for $\mathbf{1 a}$, although, the amino substituent offers significantly more stabilization to the benzyl radical. Corrie et al. have shown that nitrobenzyl based chelators with $-\mathrm{NH}-\mathrm{CH}_{2}-\mathrm{COO}^{-}$substituents in the benzylic position undergo photoinduced intramolecular electron transfer from the amine to the nitro group, which leads to decarboxylation next to intramolecular hydrogen atom transfer and thus diminishes the yield of LG release. ${ }^{37}$

In our case decarboxylation is impossible, but non-productive electron transfer may compete with hydrogen atom transfer and thus lead to the surprisingly small quantum yield observed for 1b. Conjugation of the amine nitrogen with a carbonyl function, as it is the case in $\mathbf{1 c}$ and $\mathbf{1 d}$, prevents this photoinduced charge transfer process from occurring, because the ionization energies of monoalkyl amides are approximately $1 \mathrm{eV}$ higher than those of dialkylamines. ${ }^{38}$

We also calculated the enthalpy change $\Delta_{\mathrm{r}} H$ for the thermal HAT $(9 \rightarrow \mathbf{1 0}$, Scheme 4), using the same methods as for the RSEs (for details, see ESI $\dagger$ ), because these values should correlate, by virtue of the Bell-Evans-Polanyi principle, with the barriers for the reverse HAT process (iii) which competes with the cyclization (ii), as shown in Scheme 5.

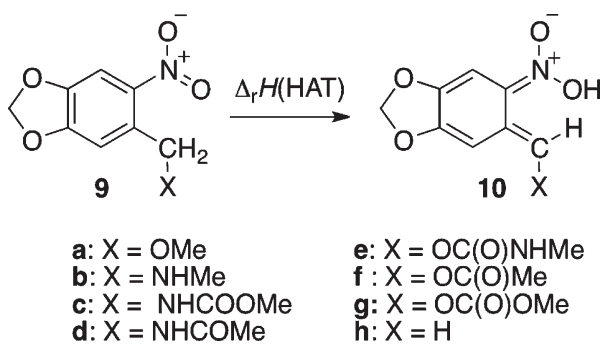

Scheme 4

It turned out that the same substituents which stabilize the benzyl radicals $9^{\circ}$ (and thus weaken the critical $\mathrm{C}-\mathrm{H}$ bond and lower $E_{\mathrm{a}}\left(\mathrm{HAT}^{*}\right)$ ) stabilize also the aci-nitro compounds $\mathbf{1 0}$

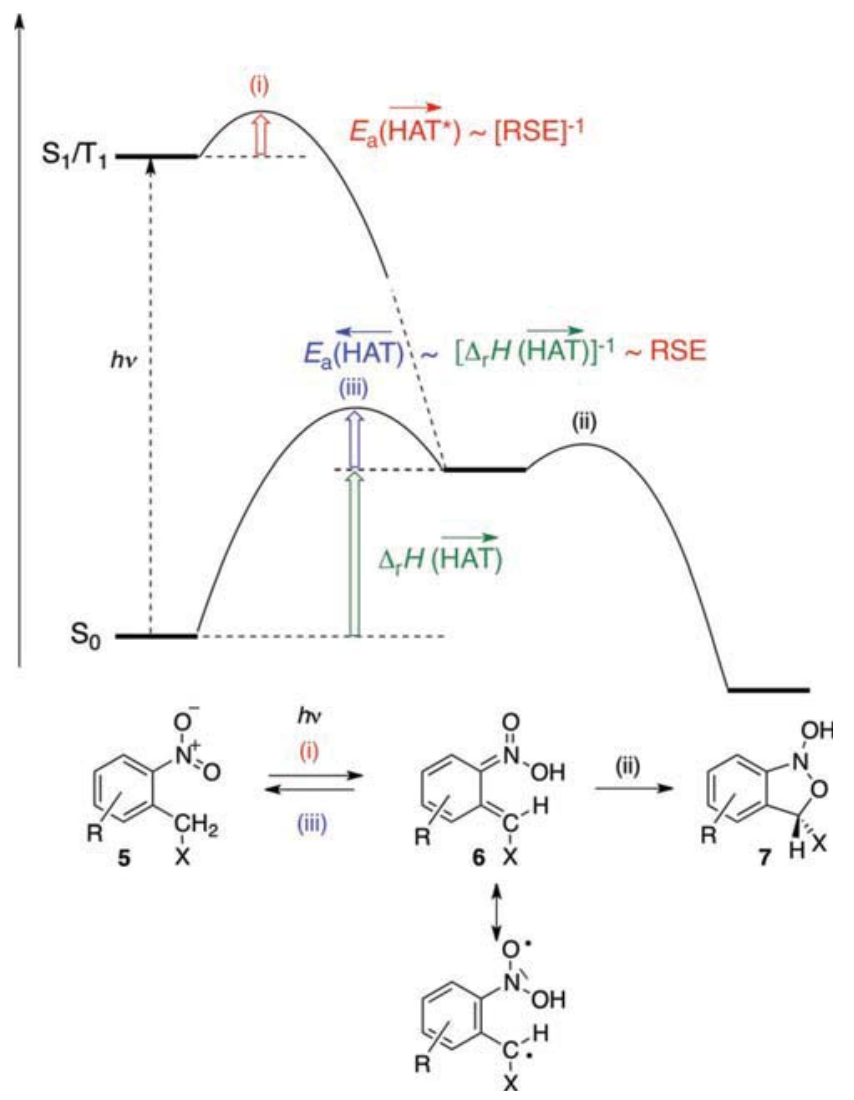

Scheme 5 Scheme including the pivotal steps in the photoreactions of $o$-nitrobenzyl PPGs. Note that the size of the blue vertical arrow is inversely proportional to that of the green one by virtue of the Bell-EvansPolanyi principle. The size of the red and the green vertical arrows diminishes with increasing RSE, while that of the blue one increases.

relative to the nitrobenzyl compounds $\mathbf{9}$, i.e. decrease $\Delta_{\mathrm{r}} H$ (HAT) and thus increase the barrier for the thermal back HAT, $E_{\mathrm{a}}$ (HAT). Thereby the productive cyclization process (ii) is favored over thermal back HAT (iii). Naturally, the outcome of the reaction is also influenced by the barrier for process (iii), which we did not consider in the present study. As shown by Il'ichev, ${ }^{30}$ the (ii)/

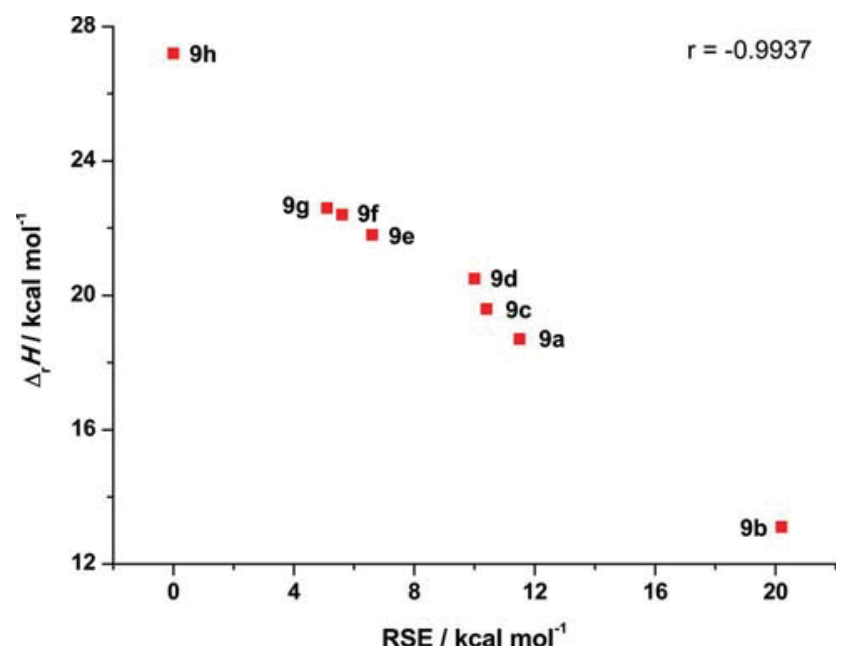

Fig. 3 Linear correlation of $\Delta_{\mathrm{r}} H(\mathbf{9} \rightarrow \mathbf{1 0})$ with the RSEs for radicals $\mathbf{9}$. (Scheme 3). Correlation coefficient is shown. 
(iii) branching ratio varies very little for LGs of the type presently considered. However, the (ii)/(iii) branching ratio may differ substantially for other substituents $X$ than those in Scheme 3. In such case the barrier for the reverse HAT really comes to bear.

In fact, the $\Delta_{\mathrm{r}} H(\mathrm{HAT})$ and the RSEs correlate quite well, as shown in Fig. 3, which may be explained by the fact that a diradical resonance structure contributes significantly to $\mathbf{6}$, as shown in Scheme 5.

Finally, we also considered the possibility that deprotonation of the aci-nitro compounds $\mathbf{6}$ may compete with cyclization (which is unlikely under our experimental conditions, but must be accounted for in proton accepting solvents). The relative rates of this process will depend on the relative $\mathrm{p} K_{\mathrm{A}}$ of compounds $\mathbf{6}$. We calculated the relative deprotonation energies of $\mathbf{1 0}$ and found that these, too, correlate quite well with the RSEs (for details, see Scheme S1, Table S4 and Fig. S1 in the ESI $\dagger$ ), i.e. substituents X which stabilize radicals $9^{-}$decrease the acidity of aci-nitro compounds $\mathbf{1 0}$ and therefore decrease the rate of deprotonation at given experimental conditions, hence favoring again the irreversible cyclization which precedes the LG release.

Thus, the radical stabilization energy (RSE), which can be readily calculated by the methods we have used in this study, appears to be a good measure of the capacity of different leaving groups (LGs) to affect the efficiency with which they are photoreleased from $o$-nitrobenzyl PPGs.

\section{Conclusions}

We have measured quantum yields for the photoinduced release of seven different commonly used leaving groups (LGs) from $o$ nitroveratryl protecting groups, and found that these quantum yields depend strongly on the nature of the LG. We have shown that the quantum efficiency with which LGs are released correlates with the stabilization that the LGs provide to $o$-nitrobenzyltype radicals. We rationalize this by arguing that radical stabilizing groups weaken the $\mathrm{C}-\mathrm{H}$ bond that is cleaved in the photoinduced hydrogen atom transfer step, and hence lower the barrier for this process. At the same time these substituents lower the endothermicity of the thermal hydrogen atom transfer and thus increase the barrier for the reverse process, thereby augmenting the chances for the competing cyclization reaction (which ultimately leads to LG release). Radical stabilization energies are thus a useful predictor of the relative efficiency with which LGs are photoreleased from $o$-nitrobenzyl protecting groups.

\section{Methods}

\subsection{General procedures}

Unless otherwise indicated, all starting materials were obtained from commercial suppliers (Fluka, Sigma, Across) and were used without further purification. Deuterated solvents such as acetonitrile, chloroform, and water were obtained from Cambridge Isotope Laboratories. Solvents were dried on Alox and degassed with argon. Analytical thin layer chromatography was performed on Kieselgel F-254 pre-coated aluminium sheets TLC plates from Merck. Visualization was performed with, either a $254 \mathrm{~nm}$ ultraviolet lamp, or a $\mathrm{KMnO}_{4}$ solution. Silica gel column chromatography was carried out with silica gel (32-63, $60 \AA$ ) from Brunschwig. The ${ }^{1} \mathrm{H}$ and ${ }^{13} \mathrm{C}$ NMR spectra were recorded on a Brucker 360 or $500 \mathrm{MHz}$ in $\mathrm{CDCl}_{3}$. Chemical shifts are expressed in parts per million $(\delta, \mathrm{ppm})$ using residual solvent protons as internal standards: chloroform $(\delta 7.26 \mathrm{ppm}$ for ${ }^{1} \mathrm{H}, \delta 77.16 \mathrm{ppm}$ for $\left.{ }^{13} \mathrm{C}\right)$, acetonitrile $\left(\delta 1.94 \mathrm{ppm}\right.$ for $\left.{ }^{1} \mathrm{H}\right)$, $\mathrm{CD}_{3} \mathrm{OD}\left(\delta 3.31 \mathrm{ppm}\right.$ for $\left.{ }^{1} \mathrm{H}\right)$. Coupling constant $(J)$ are reported in Hz. Splitting patterns are designated as s (singlet), d (doublet), $\mathrm{t}$ (triplet), q (quartet), br s (broad singlet), m (multiplet).

High performance liquid chromatography (HPLC) was done using a Dionex Acclaim ${ }^{\circledR} 120 \mathrm{C} 183 \mathrm{~mm} 120 \AA$, $2.1 \times 100 \mathrm{~mm}$ column equipped with an ASI-100 Automated Sample Injector, a P580 Pump and a PDA-100 Photodiode Array Detector. ESI-HRMS mass spectra were obtained by Brucker FTMS 4.7T BioAPEX II. IR spectroscopy was done on Mattson Galaxy Series 5000 FT-IR in $\mathrm{CHCl}_{3}$ or neat on a $\mathrm{NaCl}$ cell. UV spectra were recorded with a Perkin Elmer Lambda 25 UV/VIS Spectrometer. The photolyses were carried out in a LED-based photoreactor (model LUMOS, Atlas Photonics).

Photon flux determination for the LEDs $(254 \mathrm{~nm})$ of the LUMOS photoreactor. In a square quartz cell $(1 \mathrm{~cm})$, a solution of phenylglyoxylic acid $\left(2.5 \times 10^{-2} \mathrm{M}, \mathrm{A}>3\right)$ in $\mathrm{MeCN}: \mathrm{H}_{2} \mathrm{O}$ $(3: 1)$ was irradiated and UV spectra of the solution were recorded every $30 \mathrm{~min}$. The absorbance of the solution was followed at $390 \mathrm{~nm}(A<1)$ to convert it to a conversion rate.

Photon flux determination for the LEDs $(360 \mathrm{~nm})$ of the LUMOS photoreactor. In a square quartz cell $(1 \mathrm{~cm})$, a solution of phenylglyoxylic acid $\left(5 \times 10^{-2} \mathrm{M}, A \sim 3\right)$ in $\mathrm{MeCN}: \mathrm{H}_{2} \mathrm{O}$ (3:1) was irradiated and UV spectra of the solution were recorded every $5 \mathrm{~min}$. The absorbance of the solution was followed at $390 \mathrm{~nm}(A<1)$ to convert it to a conversion rate.

Determination of quantum yields at $254 \mathrm{~nm}$ and $360 \mathrm{~nm}$. In a square quartz cell $(1 \mathrm{~cm})$, an acetonitrile solution of compound 1a-g $\left(1 \times 10^{-3} \mathrm{M}, A>5\right)$ was irradiated for the required time to obtain a conversion rate lower than $10 \%$. The conversion rate was determined by HPLC, after addition of an internal standard of known concentration (valerophenone).

\subsection{Syntheses}

(4,5-Dimethoxy-2-nitrophenyl)methanol. To a solution of 6nitroveratraldehyde $(2 \mathrm{~g}, 9.5 \mathrm{mmol})$ in $40 \mathrm{~mL}$ of methanol $\mathrm{NaBH}_{4}$ (180 mg, $\left.4.7 \mathrm{mmol}\right)$ was slowly added. The mixture was stirred at room temperature for $2 \mathrm{~h}$. The solvent was then evaporated, and the residue was partitioned between AcOEt and water. After extraction with AcOEt, the combined organic layers were washed with brine, dried with $\mathrm{MgSO}_{4}$, filtered, and evaporated. The desired product was obtained as a yellow powder without further purification $(1.94 \mathrm{~g}, 96 \%) .{ }^{1} \mathrm{H}$ NMR $\left(\mathrm{CDCl}_{3}\right): \delta(\mathrm{ppm})$ $2.34(1 \mathrm{H}$, br s), $3.95(3 \mathrm{H}, \mathrm{s}), 3.99(3 \mathrm{H}, \mathrm{s}), 4.95(2 \mathrm{H}, \mathrm{s}), 7.17$ $(1 \mathrm{H}, \mathrm{s}), 7.70(1 \mathrm{H}, \mathrm{s})$.

1-(Bromomethyl)-4,5-dimethoxy-2-nitrobenzene. To a stirred solution of (4,5-dimethoxy-2-nitrophenyl)methanol (1 g, $4.7 \mathrm{mmol})$ in dry toluene $(120 \mathrm{~mL})$ and 8 drops of pyridine at $0{ }^{\circ} \mathrm{C}$, phosphorus tribromide $(725 \mathrm{mg}, 2.7 \mathrm{mmol})$ was added dropwise. The mixture was allowed to warm to r.t. and stirred 
overnight. Then, water was added and the mixture was extracted with $\mathrm{Et}_{2} \mathrm{O}$. The organic layer was dried with $\mathrm{MgSO}_{4}$, filtered and the solvent was removed to obtain the crude residue which was purified by flash chromatography $\left(\mathrm{SiO}_{2}, \mathrm{CH}_{2} \mathrm{Cl}_{2}\right.$ : pentane, $\left.1: 1\right)$ to give the desired product as a yellow solid $(780 \mathrm{mg}, 60 \%) .{ }^{1} \mathrm{H}$ NMR $\left(\mathrm{CDCl}_{3}\right): \delta$ (ppm) $3.96(3 \mathrm{H}, \mathrm{s}), 4.00(3 \mathrm{H}, \mathrm{s}), 4.87(2 \mathrm{H}, \mathrm{s})$, $6.94(1 \mathrm{H}, \mathrm{s}), 7.68(1 \mathrm{H}, \mathrm{s})$.

1,2-Dimethoxy-4-nitro-5-(octyloxymethyl)benzene 1a. To a stirred solution of 1-octanol $(50 \mathrm{mg}, 0.385 \mathrm{mmol})$ and nitroveratryl bromide $(317 \mathrm{mg}, 1.15 \mathrm{mmol})$ in dry $\mathrm{CH}_{2} \mathrm{Cl}_{2}(2.5 \mathrm{~mL})$ in a Schlenk tube, silver oxide $(266.5 \mathrm{mg}, 1.15 \mathrm{mmol})$ was added and the mixture was stirred at $45^{\circ} \mathrm{C}$ under argon for 9 days protected from light. Then the mixture was filtered and the solvent was evaporated. Purification by flash chromatography $\left(\mathrm{SiO}_{2}\right.$, $\mathrm{CH}_{2} \mathrm{Cl}_{2}$ : pentane, $2: 1$ ) gave the desired product as a yellow solid (43.3 mg, 35\%). ${ }^{1} \mathrm{H}$ NMR $\left(\mathrm{CDCl}_{3}\right): \delta(\mathrm{ppm}) 0.88(3 \mathrm{H}, \mathrm{m})$, 1.27-1.44 (10H, m), 1.68 (2H, m), 3.59 (2H, t, $J=6.6 \mathrm{~Hz}), 3.95$ $(3 \mathrm{H}, \mathrm{s}), 3.99(3 \mathrm{H}, \mathrm{s}), 4.89(2 \mathrm{H}, \mathrm{s}), 7.32(1 \mathrm{H}, \mathrm{s}), 7.70(1 \mathrm{H}, \mathrm{s})$. ${ }^{13} \mathrm{C}$ NMR $\left(\mathrm{CDCl}_{3}\right): \delta(\mathrm{ppm}) 14.2,22.8,26.5,29.4,29.6,29.9$, 32.0, 56.5, 56.5, 69.6, 71.6, 108.0, 109.5, 131.7, 139.3, 147.6, 153.9. IR $\left(\mathrm{CHCl}_{3}\right): 3023,2960,2931,2855,1582,1520,1464$, $1328,1275,1216,1105,1064,876 \mathrm{~cm}^{-1}$. HRMS (ESI): $\left(\mathrm{M}-\mathrm{Na}^{+}\right)$348.1787, found 348.1783.

$N$-(4,5-Dimethoxy-2-nitrobenzyl)dodecan-1-amine 1b. A stirred mixture of 6-nitroveratraldehyde ( $2.1 \mathrm{~g}, 10 \mathrm{mmol})$, 1-dodecylamine $(2.04 \mathrm{~g}, 11 \mathrm{mmol})$ and $\mathrm{Na}_{2} \mathrm{SO}_{4}(1.56 \mathrm{~g}, 11 \mathrm{mmol})$ in dry toluene $(20 \mathrm{~mL})$ under $\mathrm{N}_{2}$ was stirred overnight at reflux with a Dean-Stark apparatus. Then, the solvent was removed and the residue was dissolved in dry $\mathrm{MeOH}(200 \mathrm{~mL}) . \mathrm{NaBH}_{4}$ (378 $\mathrm{mg}, 10 \mathrm{mmol}$ ) was added and the mixture was stirred for $2 \mathrm{~h}$ at r.t. Then the solvent was removed, the residue was dissolved in $\mathrm{CH}_{2} \mathrm{Cl}_{2}$ and washed with $\mathrm{H}_{2} \mathrm{O}$. Flash chromatography $\left(\mathrm{SiO}_{2}\right.$, hexane : AcOEt, 9:1) gave the desired product as a yellow solid $(2.70 \mathrm{~g}, 71 \%)$. ${ }^{1} \mathrm{H}$ NMR $\left(\mathrm{CDCl}_{3}\right): \delta$ (ppm) 0.85 $(3 \mathrm{H}, \mathrm{m}), 1.18-1.37(18 \mathrm{H}, \mathrm{m}), 1.51(2 \mathrm{H}, \mathrm{m}), 1.74(1 \mathrm{H}, \mathrm{br} \mathrm{s})$, $2.63(2 \mathrm{H}, \mathrm{t}, J=7.0 \mathrm{~Hz}), 3.92(3 \mathrm{H}, \mathrm{s}), 3.97(3 \mathrm{H}, \mathrm{s}), 4.02(2 \mathrm{H}, \mathrm{s})$, $7.13(1 \mathrm{H}, \mathrm{s}), 7.62(1 \mathrm{H}, \mathrm{s}) .{ }^{13} \mathrm{C} \mathrm{NMR}\left(\mathrm{CDCl}_{3}\right): \delta(\mathrm{ppm}) 14.2$, $22.8,27.5,29.7,29.7,29.7,29.8,29.8,29.8,30.3,32.0,49.9$, $51.6,56.4,56.5,108.2,112.5,131.6,141.0,147.6,153.4$. IR $\left(\mathrm{CHCl}_{3}\right): 3065,3019,2951,2928,2855,1582,1520,1464$, $1440,1427,1361,1332,1273,1215,1210,1175,1063$, $929 \mathrm{~cm}^{-1}$. HRMS (ESI): $\left(\mathrm{M}-\mathrm{H}^{+}\right)$381.2753, found 381.2755.

Nonyl 4,5-dimethoxy-2-nitrobenzylcarbamate 1c. To a stirred solution of $4(140 \mathrm{mg}, 0.66 \mathrm{mmol})$ and $\mathrm{Et}_{3} \mathrm{~N}(80 \mathrm{mg}$, $0.80 \mathrm{mmol})$ in dry $\mathrm{CH}_{2} \mathrm{Cl}_{2}(1 \mathrm{~mL})$ at $0{ }^{\circ} \mathrm{C}$ under argon, nonyl carbonochloridate $(164 \mathrm{mg}, 0.79 \mathrm{mmol})$ was added. Then the mixture was stirred at r.t. overnight and the solvent was evaporated. Flash chromatography $\left(\mathrm{SiO}_{2}, \mathrm{CH}_{2} \mathrm{Cl}_{2}\right)$ of the residue gave the desired product in the presence of residual 1-nonanol. Heating at $60{ }^{\circ} \mathrm{C}$ for several hours gave the desired product as a yellow solid (163 mg, 65\%). ${ }^{1} \mathrm{H}$ NMR $\left(\mathrm{CDCl}_{3}\right): \delta(\mathrm{ppm}) 0.87$ $(3 \mathrm{H}, \mathrm{m}), 1.20-1.35(12 \mathrm{H}, \mathrm{m}), 1.58(2 \mathrm{H}, \mathrm{m}), 3.94(3 \mathrm{H}, \mathrm{s}), 3.98$ $(3 \mathrm{H}, \mathrm{s}), 4.03(2 \mathrm{H}, \mathrm{t}, J=6.6 \mathrm{~Hz}), 4.56(2 \mathrm{H}, \mathrm{d}, J=6.9 \mathrm{~Hz}), 5.60$ $(1 \mathrm{H}$, br t $), 7.05(1 \mathrm{H}, \mathrm{s}), 7.67(1 \mathrm{H}, \mathrm{s}) .{ }^{13} \mathrm{C} \mathrm{NMR}\left(\mathrm{CDCl}_{3}\right): \delta$ (ppm) 14.2, 22.8, 26.0, 29.1, 29.4, 29.4, 29.6, 32.0, 43.5, 56.5, $56.7,65.5,108.3,113.9,129.4,140.7,148.4,153.7,157.0$. IR $\left(\mathrm{CHCl}_{3}\right): 3452,3065,3017,2962,2952,2931,2856,1711$,
$1584,1523,1499,1462,1440,1332,1275,1216,1143,1063$, $929 \mathrm{~cm}^{-1}$. HRMS (ESI): (M-Na ${ }^{+}$405.2002, found 405.1990.

$N$-(4,5-Dimethoxy-2-nitrobenzyl)dodecanamide 1d. To a stirred mixture of lauroyl chloride $(125 \mathrm{mg}, 0.57 \mathrm{mmol})$ in $\mathrm{CH}_{2} \mathrm{Cl}_{2} /$ sat. $\mathrm{NaHCO}_{3}(1: 1,2 \mathrm{~mL}), 4$ (145 mg, $\left.0.68 \mathrm{mmol}\right)$ was added and the mixture was stirred overnight. Then, the biphasic solution was partitioned between $\mathrm{CH}_{2} \mathrm{Cl}_{2}$ and sat. $\mathrm{NaHCO}_{3}$. The organic layer was washed with brine, dried over $\mathrm{MgSO}_{4}$, filtered and evaporated to afford the desired product as a yellow solid (224 mg, 99\%). ${ }^{1} \mathrm{H}$ NMR $\left(\mathrm{CDCl}_{3}\right): \delta$ (ppm) 0.87 (3H, m), $1.20-1.33(16 \mathrm{H}, \mathrm{m}), 1.60(2 \mathrm{H}, \mathrm{m}), 2.16(2 \mathrm{H}, \mathrm{m}), 3.94(3 \mathrm{H}, \mathrm{s})$, $3.98(3 \mathrm{H}, \mathrm{s}), 4.62(2 \mathrm{H}, \mathrm{d}, J=6.3 \mathrm{~Hz}), 6.41(1 \mathrm{H}, \mathrm{br} \mathrm{t}, J=6.1$ $\mathrm{Hz}), 7.10(1 \mathrm{H}, \mathrm{s}), 7.65(1 \mathrm{H}, \mathrm{s}) .{ }^{13} \mathrm{C} \mathrm{NMR}\left(\mathrm{CDCl}_{3}\right): \delta(\mathrm{ppm})$ $14.3,22.8,25.8,29.4,29.5,29.5,29.6,29.7,29.7,32.0,36.9$, $41.8,56.5,56.8,108.2,114.5,129.1,140.8,148.4,153.8,173.4$. IR $\left(\mathrm{CHCl}_{3}\right): 3452,3067,3020,2951,2929,2855,1668,1583$, $1523,1498,1465,1439,1424,1332,1275,1213,1219,1062$, $929 \mathrm{~cm}^{-1}$. HRMS (ESI): (M-Na ${ }^{+}$417.2365, found 417.2357.

4,5-Dimethoxy-2-nitrobenzyl dodecylcarbamate 1e. To a stirred solution of 1-dodecylamine $(185 \mathrm{mg}, 1.0 \mathrm{mmol})$ and $\mathrm{Et}_{3} \mathrm{~N}(121 \mathrm{mg}, 1.2 \mathrm{mmol})$ in dry $\mathrm{CH}_{2} \mathrm{Cl}_{2}(1 \mathrm{~mL})$ at $0{ }^{\circ} \mathrm{C}$ under argon, nitroveratryl chloroformate $(331 \mathrm{mg}, 1.2 \mathrm{mmol})$ was added. Then the mixture was stirred at r.t. overnight and the solvent was evaporated. Flash chromatography $\left(\mathrm{SiO}_{2}, \mathrm{CH}_{2} \mathrm{Cl}_{2}\right)$ of the residue gave the desired product as a off-white solid (270 mg, 64\%). ${ }^{1} \mathrm{H}$ NMR $\left(\mathrm{CDCl}_{3}\right): \delta(\mathrm{ppm}) 0.88(3 \mathrm{H}, \mathrm{m})$, $1.20-1.36(18 \mathrm{H}, \mathrm{m}), 1.51(2 \mathrm{H}, \mathrm{m}), 3.21(2 \mathrm{H}, \mathrm{dt}, J=6.9 \mathrm{~Hz})$, $3.95(3 \mathrm{H}, \mathrm{s}), 3.97(3 \mathrm{H}, \mathrm{s}), 4.83(1 \mathrm{H}, \mathrm{br} \mathrm{m}), 5.50(2 \mathrm{H}, \mathrm{s}), 7.00$ $(1 \mathrm{H}, \mathrm{s}), 7.70(1 \mathrm{H}, \mathrm{s}) .{ }^{13} \mathrm{C} \mathrm{NMR}\left(\mathrm{CDCl}_{3}\right): \delta(\mathrm{ppm}) 14.3,22.8$, 26.9, 29.4, 29.5, 29.7, 29.7, 29.8, 29.8, 30.1, 32.0, 41.4, 56.5, $56.5,63.6,108.3,110.4,128.4,140.1,148.2,153.6,156.0$. IR $\left(\mathrm{CHCl}_{3}\right): 3451,3065,3020,2951,2928,2855,1722,1583$, $1525,1465,1440,1425,1379,1331,1278,1219,1211,1134$, 1068, 1033, $928 \mathrm{~cm}^{-1}$. HRMS (ESI): $\left({\left.\mathrm{M}-\mathrm{Na}^{+}\right)}^{+} 447.2471\right.$, found 447.2468 .

4,5-Dimethoxy-2-nitrobenzyl tridecanoate 1f. To a stirred solution of tridecanoic acid $(214.3 \mathrm{mg}, 1.0 \mathrm{mmol}), o$-nitroveratrol (1.06 g, $5.0 \mathrm{mmol})$ and DMAP $(24.5 \mathrm{mg}, 0.2 \mathrm{mmol})$ in dry $\mathrm{CH}_{2} \mathrm{Cl}_{2}(3.4 \mathrm{~mL})$ at $0{ }^{\circ} \mathrm{C}$ under argon, DCC $(247.7 \mathrm{mg}$, $1.2 \mathrm{mmol}$ ) was added and the mixture was stirred for $3 \mathrm{~h}$ at r.t. Then the reaction mixture was filtered through a pad of Celite and the filtrate was evaporated. Purification of the residue by flash column chromatography $\left(\mathrm{SiO}_{2}, \mathrm{CH}_{2} \mathrm{Cl}_{2}\right.$ : pentane, $\left.2: 1\right)$ gave the desired product as a slightly yellow solid (334 mg, $82 \%) .{ }^{1} \mathrm{H}$ NMR $\left(\mathrm{CDCl}_{3}\right): \delta(\mathrm{ppm}) 0.88(3 \mathrm{H}, \mathrm{m}), 1.20-1.37$ $(18 \mathrm{H}, \mathrm{m}), 1.68(2 \mathrm{H}, \mathrm{m}), 2.41(2 \mathrm{H}, \mathrm{t}, J=7.6 \mathrm{~Hz}), 3.96(3 \mathrm{H}, \mathrm{s})$, $3.98(3 \mathrm{H}, \mathrm{s}), 5.51(2 \mathrm{H}, \mathrm{s}), 7.00(1 \mathrm{H}, \mathrm{s}), 7.72(1 \mathrm{H}, \mathrm{s}) .{ }^{13} \mathrm{C} \mathrm{NMR}$ $\left(\mathrm{CDCl}_{3}\right): \delta(\mathrm{ppm}) 14.3,22.8,25.2,29.3,29.4,29.5,29.6,29.7$, 29.8, 29.8, 32.1, 34.5, 56.5, 56.6, 63.2, 108.4, 110.6, 127.4, 140.2, 148.4, 153.6, 173.3. IR $\left(\mathrm{CHCl}_{3}\right): 3065,3020,2956$, 2929, 2855, 1737, 1584, 1524, 1465, 1440, 1426, 1382, 1333, $1278,1217,1175,1068,1013,932 \mathrm{~cm}^{-1}$. HRMS (ESI): $\left(\mathrm{M}-\mathrm{Na}^{+}\right.$) 432.2362, found 432.2353.

4,5-Dimethoxy-2-nitrobenzyl decyl carbonate 1g. To a stirred solution of 1-decanol $(63.6 \mathrm{mg}, 0.40 \mathrm{mmol})$ and DMAP (98.3 $\mathrm{mg}, 0.80 \mathrm{mmol})$ in dry $\mathrm{CH}_{2} \mathrm{Cl}_{2}(1 \mathrm{~mL})$ at $0{ }^{\circ} \mathrm{C}$ under 
argon, nitroveratryl chloroformate $(133 \mathrm{mg}, 0.48 \mathrm{mmol})$ was added. Then the mixture was stirred at r.t. overnight and the solvent was evaporated. Flash chromatography $\left(\mathrm{SiO}_{2}, \mathrm{CH}_{2} \mathrm{Cl}_{2}\right)$ of the residue gave the desired product as a yellow solid (148 mg, 93\%). ${ }^{1} \mathrm{H}$ NMR $\left(\mathrm{CDCl}_{3}\right): \delta$ (ppm) 0.87 (3H, m), 1.20-1.40 (14H, m), $1.69(2 \mathrm{H}, \mathrm{m}), 3.96(3 \mathrm{H}, \mathrm{s}), 3.98(3 \mathrm{H}, \mathrm{s})$, $4.19(2 \mathrm{H}, \mathrm{t}, J=6.8 \mathrm{~Hz}), 5.58(2 \mathrm{H}, \mathrm{s}), 7.06(1 \mathrm{H}, \mathrm{s}), 7.73(1 \mathrm{H}, \mathrm{s})$. ${ }^{13} \mathrm{C}$ NMR $\left(\mathrm{CDCl}_{3}\right): \delta(\mathrm{ppm}) 14.2,22.8,25.8,28.8,29.3,29.4$, 29.6, 29.6, 32.0, 56.6, 56.6, 66.3, 68.9, 108.3, 109.9, 127.2, $139.8,148.4,153.8,155.0$. IR $\left(\mathrm{CHCl}_{3}\right): 3105,3064,3019$, 2962, 2928, 2856, 1751, 1583, 1524, 1458, 1440, 1428, 1402, $1379,1332,1278,1254,1220,1212,1169,1066,929 \mathrm{~cm}^{-1}$. HRMS (ESI): (M-Na ${ }^{+}$420.1998, found 420.1994.

4,5-Dimethoxy-2-nitrobenzaldehyde oxime 2. 2-nitroveratraldehyde (5 g, $23.7 \mathrm{mmol}$ ) and hydroxylamine hydro-chloride $(1.72 \mathrm{~g}, 24.9 \mathrm{mmol})$ were added to a $1: 1$ solution of pyridine : EtOH $(150 \mathrm{~mL})$. The mixture was refluxed for $8 \mathrm{~h}$ and solvent was then removed. The residue was suspended in $\mathrm{CH}_{2} \mathrm{Cl}_{2}$ and sat. $\mathrm{NaHCO}_{3}$ was added. Partition between organic and aqueous layers followed by washings with sat. $\mathrm{NaHCO}_{3}$ and $\mathrm{H}_{2} \mathrm{O}$, drying with $\mathrm{MgSO}_{4}$, filtration and evaporation of the organic phase gave the desired product as a yellow solid (5.16 g, 96\%). ${ }^{1} \mathrm{H}$ NMR $\left(\mathrm{CDCl}_{3}\right): \delta$ (ppm) $3.98(3 \mathrm{H}, \mathrm{s}), 4.00(3 \mathrm{H}, \mathrm{s}), 7.35(1 \mathrm{H}, \mathrm{s})$, $7.64(1 \mathrm{H}, \mathrm{s}), 8.80(1 \mathrm{H}, \mathrm{s})$.

4,5-Dimethoxy-2-nitrobenzaldehyde $O$-acetyl oxime 3 . To a solution of $2(5 \mathrm{~g}, 22.1 \mathrm{mmol})$ in dry $\mathrm{CH}_{2} \mathrm{Cl}_{2}(130 \mathrm{~mL})$ at r.t. under argon, $\mathrm{Et}_{3} \mathrm{~N}$ (4 mL, $\left.28.7 \mathrm{mmol}\right)$ was slowly added. Then after stirring for $5 \mathrm{~min}, \mathrm{Ac}_{2} \mathrm{O}(2.7 \mathrm{~mL}, 28.7 \mathrm{mmol})$ was added dropwise. The mixture was stirred for $3 \mathrm{~h}$, then $\mathrm{CH}_{2} \mathrm{Cl}_{2}$ was added and the resulting solution was washed with $\mathrm{H}_{2} \mathrm{O}$. The organic layer was dried with $\mathrm{MgSO}_{4}$, filtered and evaporated. The residue was purified by filtration $\left(\mathrm{SiO}_{2}, \mathrm{CH}_{2} \mathrm{Cl}_{2}\right)$ to give the desired product as a yellow solid (3.18 g, 54\%). ${ }^{1} \mathrm{H}$ NMR $\left(\mathrm{CDCl}_{3}\right): \delta(\mathrm{ppm}) 2.25(3 \mathrm{H}, \mathrm{s}), 4.00(3 \mathrm{H}, \mathrm{s}), 4.04(3 \mathrm{H}, \mathrm{s}), 7.44$ $(1 \mathrm{H}, \mathrm{s}), 7.70(1 \mathrm{H}, \mathrm{s}), 9.04(1 \mathrm{H}, \mathrm{s})$.

(4,5-Dimethoxy-2-nitrophenyl)methanamine 4. To a stirred suspension of $3(3 \mathrm{~g}, 11.2 \mathrm{mmol})$ in dry THF $(12 \mathrm{~mL})$ at $0{ }^{\circ} \mathrm{C}$ under argon, $\mathrm{BH}_{3} \cdot \mathrm{THF}(1 \mathrm{M}, 67 \mathrm{~mL})$ was added dropwise. The solution was then refluxed for $24 \mathrm{~h}$. After cooling to $-20{ }^{\circ} \mathrm{C}$, $\mathrm{H}_{2} \mathrm{O}(5 \mathrm{~mL})$ was added followed by addition of aq. $\mathrm{KOH}(6.8$ $\mathrm{M}, 3 \mathrm{~mL}$ ). The mixture was stirred at r.t. for $3 \mathrm{~h} . \mathrm{CH}_{2} \mathrm{Cl}_{2}$ was added $(500 \mathrm{~mL})$ and the organic layer was washed with brine and $\mathrm{H}_{2} \mathrm{O}$. After drying with $\mathrm{MgSO}_{4}$, filtration and evaporation of the solvent, the residue was purified by flash chromatography $\left(\mathrm{SiO}_{2}, \mathrm{CH}_{2} \mathrm{Cl}_{2}: \mathrm{MeOH}: \mathrm{Et}_{3} \mathrm{~N}, 95: 5: 0.5\right)$ to give the desired product as a reddish solid $(285 \mathrm{mg}, 12 \%) .{ }^{1} \mathrm{H} \mathrm{NMR}\left(\mathrm{CDCl}_{3}\right): \delta$ (ppm) $1.83(2 \mathrm{H}, \mathrm{br} \mathrm{s}), 3.95(3 \mathrm{H}, \mathrm{s}), 4.00(3 \mathrm{H}, \mathrm{s}), 4.12(2 \mathrm{H}, \mathrm{s})$, $7.07(1 \mathrm{H}, \mathrm{s}), 7.66(1 \mathrm{H}, \mathrm{s})$.

Nonyl carbonochloridate. To a stirred solution of 1-nonanol $(433 \mathrm{mg}, 3 \mathrm{mmol})$ in dry THF $(2.1 \mathrm{~mL})$ under argon, a solution of $\mathrm{COCl}_{2}$ in toluene $(5.2 \mathrm{~mL})$ was added at $0{ }^{\circ} \mathrm{C}$. Then, the mixture was stirred for $3 \mathrm{~h}$ at $0{ }^{\circ} \mathrm{C}$ and then overnight at r.t. Then a flux of argon was passed through the solution to remove the excess of $\mathrm{COCl}_{2}$. Then the solvent was removed to afford the desired product $(572 \mathrm{mg}, 92 \%) .{ }^{1} \mathrm{H}$ NMR $\left(\mathrm{CDCl}_{3}\right): \delta(\mathrm{ppm})$
$0.88(3 \mathrm{H}, \mathrm{s}), 1.20-1.40(12 \mathrm{H}, \mathrm{m}), 1.72(2 \mathrm{H}, \mathrm{m}), 4.31(2 \mathrm{H}, \mathrm{t}, J=$ $6.7 \mathrm{~Hz})$.

\subsection{Quantum chemical calculations}

All quantum chemical calculations were performed with the Gaussian 09 (revision A.02) package of programs. ${ }^{39}$ Geometries were fully optimized at the RB3LYP/6-31G(d) level of theory in the case of closed shell species. Unrestricted versions of the functionals were employed in calculations of radicals. For all stationary points, harmonic vibrational frequencies were computed to obtain the ZPVE correction, which was scaled by $0.9806 .{ }^{40}$ Single point energies at the B3LYP geometries were computed with the B2PLYP ${ }^{41}$ and M06- $2 \mathrm{X}^{42}$ functionals using the $6-311+G(3 d f, 2 p)$ basis set. These functionals have proven to perform satisfactorily well in computations of thermodynamic properties of both closed- and open-shell compounds. ${ }^{35,43-46}$ The resulting enthalpies are given at $0 \mathrm{~K}(E+$ scaled ZPVE). All the calculations were performed in gas phase as well as in a polarizable continuum to simulate the solvation effect of the surrounding solvent. The polarizable continuum model (PCM) using integral equation formalism variant (IEF-PCM), as implemented in Gaussian 09, was employed.

\section{Acknowledgements}

This work is part of project No. 200020-109316 and project No. 200020-132005 of the Swiss National Science Foundation. T.S. profited from a stipend of the SCIEX (Scientific Exchange Programme between Switzerland and the New Member States of the EU) program of the Swiss Confederation and of the Brno Ph.D. Talent program sponsored by Brno City Municipality.

\section{References}

1 R. B. Merrifield, Solid Phase Peptide Synthesis. 1. Synthesis of a Tetrapeptide, J. Am. Chem. Soc., 1963, 85, 2149-2154.

2 J. A. Barltrop and P. Schofield, Organic photochemistry. II. Some photosensitive protecting groups, J. Chem. Soc., 1965, 4758-4765.

3 J. A. Barltrop, P. J. Plant and P. Schofield, Photosensitive protective groups, J. Chem. Soc., Chem. Commun., 1966, 822-823.

4 A. Patchornik, B. Amit and R. B. Woodward, Photosensitive protecting groups, J. Am. Chem. Soc., 1970, 92, 6333-6335.

5 V. N. R. Pillai, Photoremovable protecting groups in organic synthesis, Synthesis, 1980, 1-26.

6 C. G. Bochet, Photolabile protecting groups and linkers, J. Chem. Soc., Perkin. Trans. 1, 2002, 125-142.

7 A. P. Pelliccioli and J. Wirz, Photoremovable protecting groups: reaction mechanisms and applications, Photochem. Photobiol. Sci., 2002, 1, 441458.

8 U. Jonas, A. del Campo, C. Kruger, G. Glasser and D. Boos, Colloidal assemblies on patterned silane layers, Proc. Natl. Acad. Sci. U. S. A., 2002, 99, 5034-5039.

9 A. del Campo, D. Boos, H. W. Spiess and U. Jonas, Surface modification with orthogonal photosensitive silanes for sequential chemical lithography and site-selective particle deposition, Angew. Chem., Int. Ed., 2005, 44, 4707-4712.

10 V. San Miguel, C. G. Bochet and A. del Campo, Wavelength-Selective Caged Surfaces: How Many Functional Levels Are Possible?, J. Am. Chem. Soc., 2011, 133, 5380-5388.

11 J. H. Kaplan, B. Forbush, III and J. F. Hoffman, Rapid photolytic release of adenosine 5 '-triphosphate from a protected analog: utilization by the sodium:potassium pump of human red blood cell ghosts, Biochemistry, 1978, 17, 1929-1935. 
12 S. R. Adams and R. Y. Tsien, Controlling cell chemistry with caged compounds, Annu. Rev. Physiol., 1993, 55, 755-784.

13 G. Mayer and A. Heckel, Biologically active molecules with a "light switch", Angew. Chem., Int. Ed., 2006, 45, 4900-4921.

14 K. C. Nicolaou, C. W. Hummel, E. N. Pitsinos, M. Nakada, A. L. Smith, K. Shibayama and H. Saimoto, Total synthesis of calicheamicin gamma-1 (I), J. Am. Chem. Soc., 1992, 114, 10082-10084.

15 S. P. A. Fodor, R. P. Rava, X. H. C. Huang, A. C. Pease, C. P. Holmes and C. L. Adams, Multiplexed biochemical assays with biological chips, Nature, 1993, 364, 555-556.

16 M. C. Pirrung, How to make a DNA chip, Angew. Chem., Int. Ed., 2002, 41, 1276-1289.

17 G. C. R. Ellis-Davies, Caged compounds: photorelease technology for control of cellular chemistry and physiology, Nat. Methods, 2007, 4, 619-628.

18 M. Schwörer and J. Wirz, Photochemical reaction mechanisms of 2-nitrobenzyl compounds in solution I. 2-nitrotoluene: Thermodynamic and kinetic parameters of the aci-nitro tautomer, Helv. Chim. Acta, 2001, 84, $1441-1458$

19 Y. V. Il'ichev, M. A. Schwörer and J. Wirz, Photochemical Reaction Mechanisms of 2-Nitrobenzyl Compounds: Methyl Ethers and Caged ATP, J. Am. Chem. Soc., 2004, 126, 4581-4595.

20 M. Gaplovsky, Y. V. Il'ichev, Y. Kamdzhilov, S. V. Kombarova, M. Mac, M. A. Schworer and J. Wirz, Photochemical reaction mechanisms of 2-nitrobenzyl compounds: 2-Nitrobenzyl alcohols form 2-nitroso hydrates by dual proton transfer, Photochem. Photobiol. Sci., 2005, 4, 33-42.

21 B. Hellrung, Y. Kamdzhilov, M. Schworer and J. Wirz, Photorelease of alcohols from 2-nitrobenzyl ethers proceeds via hemiacetals and may be further retarded by buffers intercepting the primary aci-nitro intermediates, J. Am. Chem. Soc., 2005, 127, 8934-8935.

22 J. E. T. Corrie, A. Barth, V. R. N. Munasinghe, D. R. Trentham and M. C. Hutter, Photolytic Cleavage of 1-(2-Nitrophenyl)ethyl Ethers Involves Two Parallel Pathways and Product Release Is Rate-Limited by Decomposition of a Common Hemiacetal Intermediate, J. Am. Chem. Soc., 2003, 125, 8546-8554.

23 F. Bley, K. Schaper and H. Gorner, Photoprocesses of molecules with 2nitrobenzyl protecting groups and caged organic acids, Photochem. Photobiol., 2008, 84, 162-171.

24 T. Schmierer, S. Laimgruber, K. Haiser, K. Kiewisch, J. Neugebauer and P. Gilch, Femtosecond spectroscopy on the photochemistry of ortho-nitrotoluene, Phys. Chem. Chem. Phys., 2010, 12, 15653-15664.

25 Y. V. Il'ichev and J. Wirz, Rearrangements of 2-nitrobenzyl compounds. 1. Potential energy surface of 2-nitrotoluene and its isomers explored with ab initio and density functional theory methods, J. Phys. Chem. A, 2000, 104, 7856-7870.

26 P. Sebej, T. Šlomek, L. Hroudna, P. Brancova and P. Klan, Photochemistry of 2-Nitrobenzylidene Acetals, J. Org. Chem., 2009, 74, 86478658 .

27 A. Blanc and C. G. Bochet, Isotope effects in photochemistry. 1. o-Nitrobenzyl alcohol derivatives, J. Am. Chem. Soc., 2004, 126, 7174-7175.

28 A. Blanc and C. G. Bochet, Isotope effects in photochemistry: Application to chromatic orthogonality, Org. Lett., 2007, 9, 2649-2651.

29 L. Kammari, T. Šolomek, B. P. Ngoy, D. Heger and P. Klan, Orthogonal Photocleavage of a Monochromophoric Linker, J. Am. Chem. Soc., 2010, 132, 11431-11433.

30 Y. V. Il'ichev, Rearrangements of 2-nitrobenzyl compounds. 2. Substituent effects on the reactions of the quinonoid intermediates, J. Phys. Chem. A, 2003, 107, 10159-10170.

31 T. Schmierer, F. Bley, K. Schaper and P. Gilch, The early processes in the photochemistry of ortho-nitrobenzyl acetate, J. Photochem. Photobiol., A, 2011, 217, 363-368.
32 A. Migani, V. Leyva, F. Feixas, T. Schmierer, P. Gilch, I. Corral, L. Gonzalez and L. Blancafort, Ultrafast irreversible phototautomerization of o-nitrobenzaldehyde, Chem. Commun., 2011, 47, 6383-6385.

33 M. Yamaji, X. C. Cai, M. Sakamoto, M. Fujitsuka and T. Majima, Photodecomposition Profiles of beta-Bond Cleavage of Phenylphenacyl Derivatives in the Higher Triplet Excited States during Stepwise TwoColor Two-Laser Flash Photolysis, J. Phys. Chem. A, 2008, 112, 11306 11311.

34 M. Yamaji, X. Cai, M. Sakamoto, M. Fujitsuka and T. Majima, alphaBond Dissociation of p-Phenylbenzoyl Derivatives in the Higher Triplet Excited State Studied by Two-Color Two-Laser Flash Photolysis, J. Phys. Chem. A, 2009, 113, 1696-1703.

35 A. S. Menon, G. P. F. Wood, D. Moran and L. Radom, Bond dissociation energies and radical stabilization energies: An assessment of contemporary theoretical procedures, J. Phys. Chem. A, 2007, 111, 13638-13644.

36 A. S. Menon, D. J. Henry, T. Bally and L. Radom, Effect of substituents on the stabilities of multiply-substituted carbon-centered radicals, Org. Biomol. Chem., 2011, 9, 3636-3657.

37 A. Barth, S. R. Martin and J. E. T. Corrie, Decarboxylation is a significant reaction pathway for photolabile calcium chelators and related compounds, Photochem. Photobiol. Sci., 2006, 5, 107-115.

38 K. Kimura, S. Katsumata, Y. Achiba, T. Yamazaki and S. Iwata, Ionization energies, $\mathrm{Ab}$ initio assignments, and valence electronic structure for 200 molecules, in Handbook of HeI Photoelectron Spectra of Fundamental Organic Compounds, Japan Scientific Soc. Press, Tokyo, 1981.

39 M. J. Frisch, G. W. Trucks, H. B. Schlegel, G. E. Scuseria, M. A. Robb, J. R. Cheeseman, G. Scalmani, V. Barone, B. Mennucci, G. A. Petersson, H. Nakatsuji, M. Caricato, X. Li, H. P. Hratchian, A. F. Izmaylov, J. Bloino, G. Zheng, J. L. Sonnenberg, M. Hada, M. Ehara, K. Toyota, R. Fukuda, J. Hasegawa, M. Ishida, T. Nakajima, Y. Honda, O. Kitao, H. Nakai, T. Vreven, J. A. Montgomery, Jr., J. E. Peralta, F. Ogliaro, M. Bearpark, J. J. Heyd, E. Brothers, K. N. Kudin, V. N. Staroverov, R. Kobayashi, J. Normand, K. Raghavachari, A. Rendell, J. C. Burant, S. S. Iyengar, J. Tomasi, M. Cossi, N. Rega, J. M. Millam, M. Klene, J. E. Knox, J. B. Cross, V. Bakken, C. Adamo, J. Jaramillo, R. Gomperts, R. E. Stratmann, O. Yazyev, A. J. Austin, R. Cammi, C. Pomelli, J. Ochterski, R. L. Martin, K. Morokuma, V. G. Zakrzewski, G. A. Voth, P. Salvador, J. J. Dannenberg, S. Dapprich, A. D. Daniels, O. Farkas, J. B. Foresman, J. V. Ortiz, J. Cioslowski and D. J. Fox, GAUSSIAN 09 (Revision A.02), Gaussian, Inc., Wallingford, CT, 2009.

40 J. P. Merrick, D. Moran and L. Radom, An evaluation of harmonic vibrational frequency scale factors, J. Phys. Chem. A, 2007, 111, 1168311700 .

41 S. Grimme, Semiempirical hybrid density functional with perturbative second-order correlation, J. Chem. Phys., 2006, 124, 034108.

42 Y. Zhao and D. G. Truhlar, The M06 suite of density functionals for main group thermochemistry, thermochemical kinetics, noncovalent interactions, excited states, and transition elements: two new functionals and systematic testing of four M06-class functionals and 12 other functionals, Theor. Chem. Acc., 2007, 120, 215-241.

43 T. Schwabe and S. Grimme, Theoretical thermodynamics for large molecules: Walking the thin line between accuracy and computational cost, Acc. Chem. Res., 2008, 41, 569-579.

44 A. S. Menon, G. P. F. Wood, D. Moran and L. Radom, Bond dissociation energies and radical stabilization energies: An assessment of contemporary theoretical procedures (vol 111A, pg 13638, 2007), J. Phys. Chem. A, 2008, 112, 5554-5554.

45 Y. Zhao and D. G. Truhlar, Density functionals with broad applicability in chemistry, Acc. Chem. Res., 2008, 41, 157-167.

46 Y. Zhao and D. G. Truhlar, How well can new-generation density functionals describe the energetics of bond-dissociation reactions producing radicals?, J. Phys. Chem. A, 2008, 112, 1095-1099. 